\title{
Identification of replication-dependent and replication-independent linker histone complexes: Tpr specifically promotes replication-dependent linker histone stability
}

\author{
Pei Zhang ${ }^{1}$, Owen E. Branson², Michael A. Freitas ${ }^{2}$ and Mark R. Parthun ${ }^{1 *}$
}

\begin{abstract}
Background: There are 11 variants of linker histone $\mathrm{H} 1$ in mammalian cells. Beyond their shared abilities to stabilize and condense chromatin, the $\mathrm{H} 1$ variants have been found to have non-redundant functions, the mechanisms of which are not fully understood. Like core histones, there are both replication-dependent and replication-independent linker histone variants. The histone chaperones and other factors that regulate linker histone dynamics in the cell are largely unknown. In particular, it is not known whether replication-dependent and replication-independent linker histones interact with distinct or common sets of proteins. To better understand linker histone dynamics and assembly, we used chromatography and mass spectrometry approaches to identify proteins that are associated with replication-dependent and replication-independent $\mathrm{H} 1$ variants. We then used a variety of in vivo analyses to validate the functional relevance of identified interactions.

Results: We identified proteins that bind to all linker histone variants and proteins that are specific for only one class of variant. The factors identified include histone chaperones, transcriptional regulators, RNA binding proteins and ribosomal proteins. The nuclear pore complex protein Tpr, which was found to associate with only replication-dependent linker histones, specifically promoted their stability.

Conclusion: Replication-dependent and replication-independent linker histone variants can interact with both common and distinct sets of proteins. Some of these factors are likely to function as histone chaperones while others may suggest novel links between linker histones and RNA metabolism. The nuclear pore complex protein Tpr specifically interacts with histone $\mathrm{H} 1.1$ and $\mathrm{H} 1.2$ but not $\mathrm{H} 1 \mathrm{x}$ and can regulate the stability of these replication-dependent linker histones.
\end{abstract}

Keywords: Chromatin, Histone, Histone chaperone, Linker histone, H1, Tpr

\section{Background}

The basic repeating structural unit of eukaryotic chromatin is the nucleosome core particle (NCP), which is a structured package of $147 \mathrm{bps}$ of DNA and a histone octamer consisting of 2 copies of each core histone: H2A, $\mathrm{H} 2 \mathrm{~B}, \mathrm{H} 3$, and H4. There are also linker histones, H1, flanking NCPs and sealing the structure with about $20 \mathrm{bps}$

\footnotetext{
* Correspondence: parthun.1@osu.edu

${ }^{1}$ Department of Biological Chemistry and Pharmacology, The Ohio State University, Columbus, $\mathrm{OH}$ 43210, USA

Full list of author information is available at the end of the article
}

of additional DNA. The involvement of H1 is crucial for the formation and stabilization of chromatin structures and for the regulation of gene expression $[1,2]$.

There are 11 variants of linker histone $\mathrm{H} 1$ in mammalian cells: somatic replication-dependent variants (H1.1 to $\mathrm{H} 1.5)$, somatic replication-independent variants (H1.0, $\mathrm{H} 1 \mathrm{x})$, and germ cell specific variants (H1t, H1T2m and HILS1 for testicular cells, and H1oo for oocytes) [3]. The replication-dependent variants are typically expressed during $\mathrm{S}$ phase and are incorporated during into chromatin during DNA replication, while the replication-independent 
variants are expressed throughout the cell cycle and can be incorporated into chromatin outside of $\mathrm{S}$ phase. The sequences of these $\mathrm{H} 1$ variants vary greatly in their $\mathrm{C}$-terminal domains. The individual functions of $\mathrm{H} 1$ variants are not fully understood. It was believed that $\mathrm{H} 1$ served as a global gene regulator by binding to chromatin non-specifically. However, although partially redundant in function, there is evidence indicating $\mathrm{H} 1$ variants have distinct roles in gene regulation and development. While deleting a single $\mathrm{H} 1$ variant did not lead to any observable phenotype, the $\mathrm{H} 1.2 / \mathrm{H} 1.3 / \mathrm{H} 1.4$ triple knockout mouse exhibited developmental defects and embryonic lethality [4]. Microarray experiments showed that knockdown of each $\mathrm{H} 1$ variant altered a different subset of genes [5]. The expression levels and activities of the $\mathrm{H} 1$ variants were also found to be highly regulated during cell differentiation and tumorigenesis [6]. These observations suggest the hypothesis that each $\mathrm{H} 1$ variant has its individual function in the cells in addition to their roles as global chromatin modifiers.

Studies on core histones indicate that replicationdependent and replication-independent histone variants can be involved in distinct protein complexes and assembly pathways. For example, histone H3.1 is assembled into chromatin in coordination with DNA replication during $\mathrm{S}$ phage, while another variant, $\mathrm{H} 3.3$, is exchanged throughout the cell cycle. The dynamics of H3.1 and H3.3 are mediated by distinct protein complexes that contain different chaperones for each of the $\mathrm{H} 3$ variants. While H3.1 and H3.3 complexes have some shared histone associated proteins, such as NASP, ASF1A, ASF1B, HAT1, and importin 4, there are also exclusive histone binding partners in each complex. All three subunits of histone chaperone CAF-1 are only found in the H3.1 complex, while another histone chaperone, HIRA, is only found in the H3.3 complex [7, 8]. CAF-1 and HIRA then dictate the replication-coupled and replication-independent assembly of these $\mathrm{H} 3$ variants.

Currently it is not known whether the dynamics of replication-dependent and -independent variants of $\mathrm{H} 1$ are also regulated by distinct chaperones in a manner similar to H3.1 and H3.3 complexes. Previous studies proposed several linker histone chaperone candidates: Nucleosome Assembly Protein 1(NAP1) [9], Nuclear Autoantigenic Sperm Protein (NASP) [10], Nucleophosmin (NPM1) [11], Prothymosin $\alpha$ (ProT $\alpha)$ [12], and Template Activating Factor-I (TAF-1, also known as protein SET) [13]. The roles of these interactions between histone $\mathrm{H} 1$ and linker histone chaperones in H1 storage, transport, chromatin assembly and disassembly are not fully understood. How the linker histone chaperones interact with each $\mathrm{H} 1$ variant also remains to be determined. To better understand $\mathrm{H} 1$ variant - protein interactions, we purified non-chromatin associated protein complexes containing $6 \times$ His-tagged $\mathrm{H} 1$ variants expressed in Tetracycline-inducible U2OS cell lines using column chromatography. Proteins associated with each $\mathrm{H} 1$ variant were identified by mass spectrometry analysis. We found replication-dependent and replication-independent $\mathrm{H} 1$ variants had distinct binding partners. For example, one protein bound to replication-dependent $\mathrm{H} 1.1$ and H1.2, nucleoprotein $\mathrm{Tpr}$, was not found in the protein complex containing replication-independent H1x. Tpr knockdown leads to decreased levels of H1.1 and H1.2, but does not affect $\mathrm{H} 1 \mathrm{x}$ levels. These findings suggest that association with variant-specific binding partners may regulate linker histone dynamics.

\section{Results}

\section{Generation of inducible U2OS cell lines expressing $6 \times$ His-tagged $\mathrm{H} 1$ variants}

To purify $\mathrm{H} 1$ variants and their associated proteins for identification, we generated tetracycline-inducible U2OS cell lines over-expressing $6 \times$ His-tagged $\mathrm{H} 1$ variants $\mathrm{H} 1.1, \mathrm{H} 1.2$ or $\mathrm{H} 1 \mathrm{x}$ by transfecting U2OS cells engineered for tetracycline-inducible expression with pT-RexDEST31 plasmids carrying the corresponding $\mathrm{H} 1$ variant sequences (Fig. 1a). Cellular fractionation revealed that the vast majority of $6 \times$ His-tagged linker histones were in the nuclear fraction (Fig. 1b), indicating the exogenous H1 proteins were properly localized. Since histone proteins are highly basic, excess accumulation of histones could disrupt normal chromatin structures and cause cytotoxicity. To verify that our over-expression of $\mathrm{H} 1$ variants did not disrupt normal cell functions, we isolated total histones from uninduced and doxycycline-induced U2OS cells. Figure 1c shows a Coomassie stained gel of uninduced and induced cells expressing histone H1.1, $\mathrm{H} 1.2$ and H1x. It is clear that $\mathrm{H} 1$ induction does not result in an overall increase in linker histone abundance. MNase digestion assays further confirmed that over-expression of $6 \times$ His-tagged $\mathrm{H} 1$ variants did not significantly alter nucleosome organization or repeat length (compare time points from uninduced samples to the Dox-induced samples in Fig. 1d-f). Thus we conclude that these cell lines are suitable as the source for H1-containing protein complex purification.

\section{Purification and identification of $\mathrm{H} 1$ complexes}

To analyze proteins associating with the soluble pool of the $\mathrm{H} 1$ variants, we purified $\mathrm{H} 1.1, \mathrm{H} 1.2$ and $\mathrm{H} 1 \mathrm{x}$ from U2OS whole cell extracts by sequential chromatography with an anion exchange column (Mono Q) and an affinity column (nickel column). The specific order of the chromatography was used to optimize the concentration of proteins prior to mass spec analysis. Interestingly, H1.1 eluted in two separate peaks on the Mono Q column, while $\mathrm{H} 1.2$ and $\mathrm{H} 1 \mathrm{x}$ both eluted in only one peak 


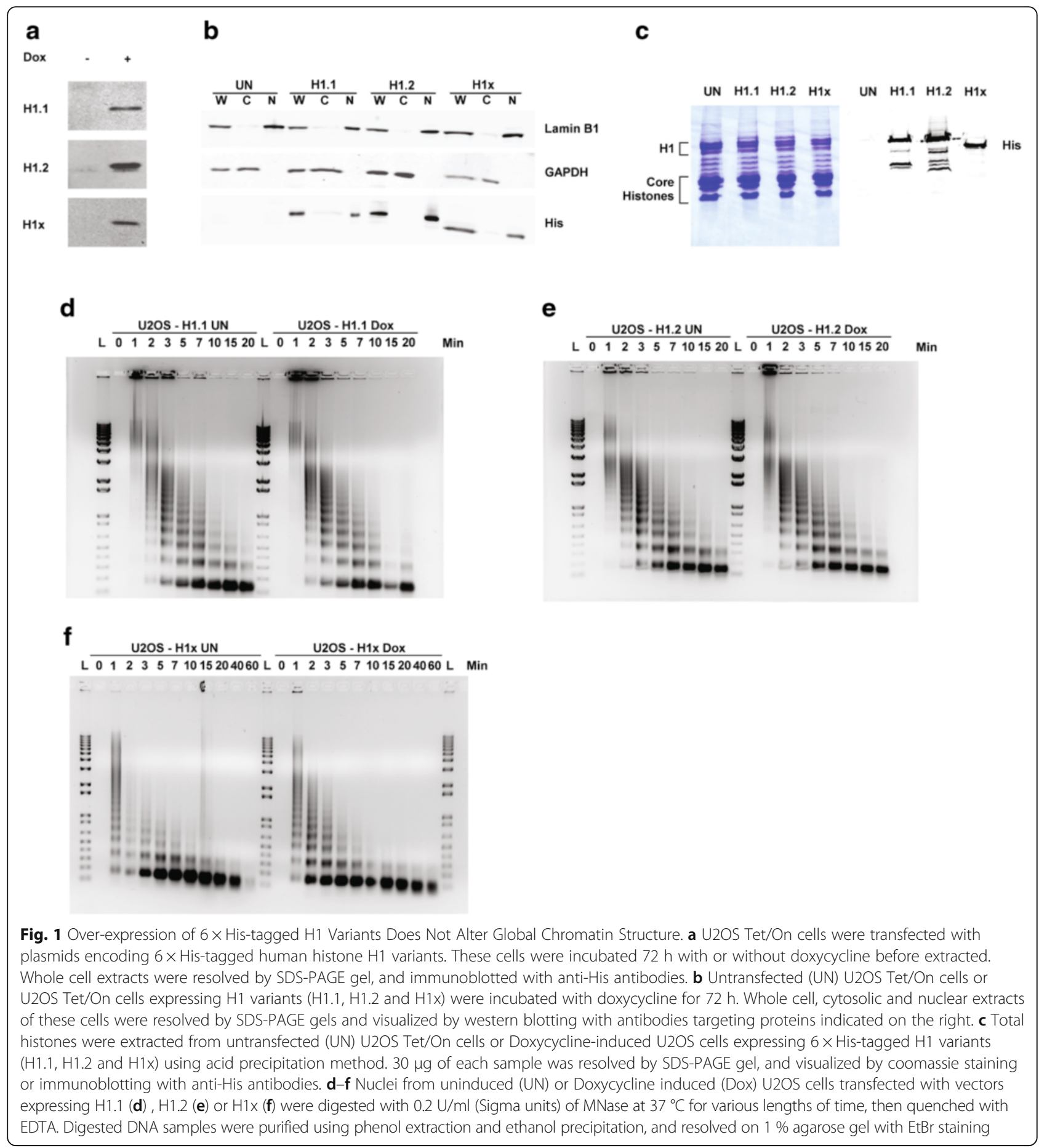

(Fig. 2a-c). Each peak eluting from the Mono Q column was collected and pooled separately, and chromatographed on a nickel chelate column (Fig. 2d-f, data not shown for the second peak of H1.1). We performed mock purification from whole cell extracts of untransfected U2OS Tet/On cells, which did not express $6 \times$ His-tagged proteins, to serve as negative controls. For the mock purifications, extracts were resolved on a Mono $\mathrm{Q}$ column and the fractions containing an equivalent salt concentration as the peak of the H1-containing fractions was then resolved on a nickel chelating column.

Peak samples eluting from the nickel chelate column containing each histone variant, as well as the comparable negative control fraction, were analyzed in duplicate by mass spectrometry. A complete list of the proteins identified, as well as the number of unique peptides observed in 
a
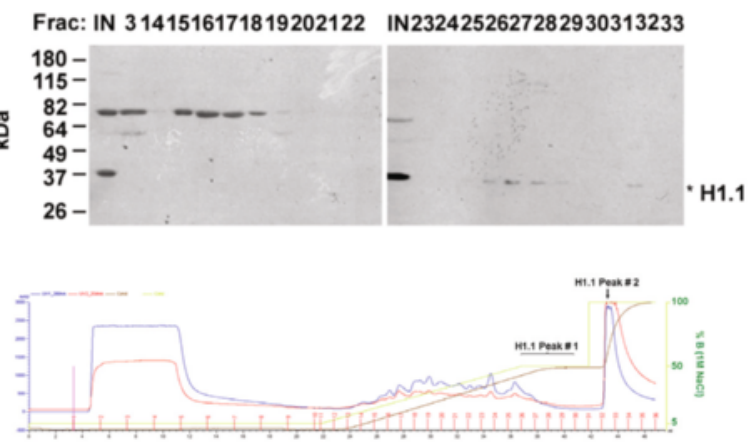

C

Frac: IN 31011121314151617181920212223242526272829303132
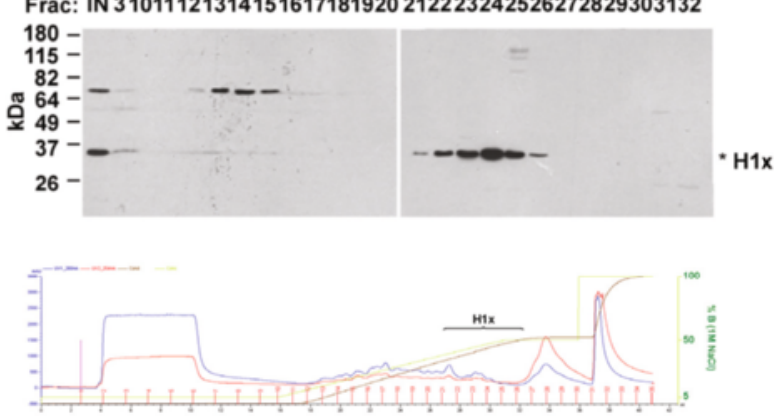

$\mathbf{e}$

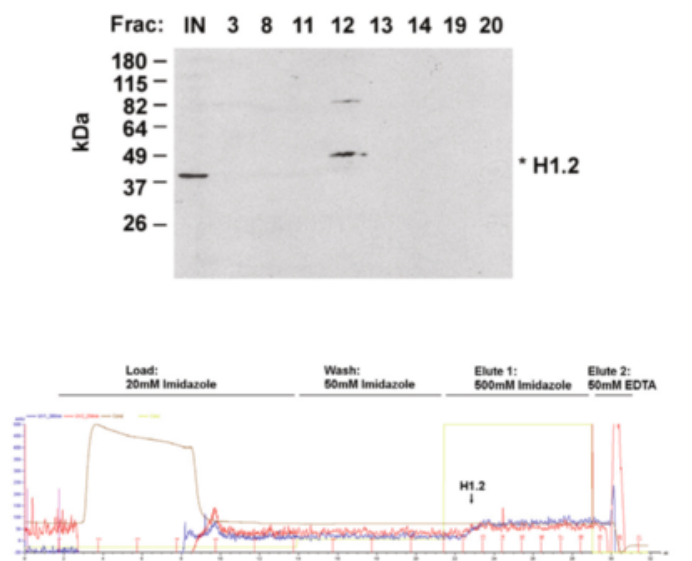

b
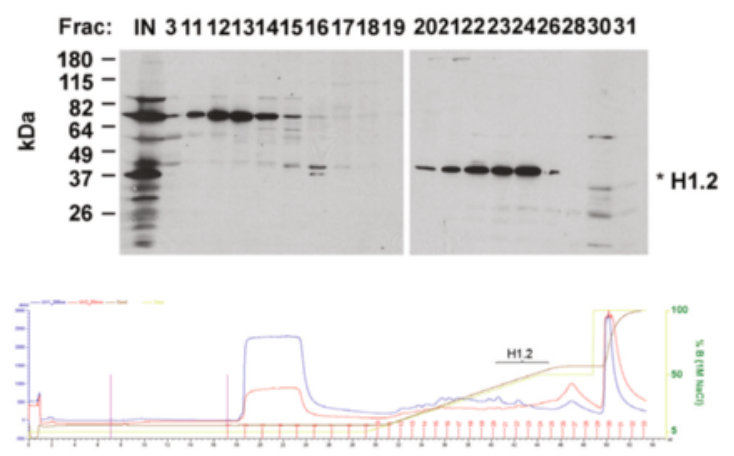

d

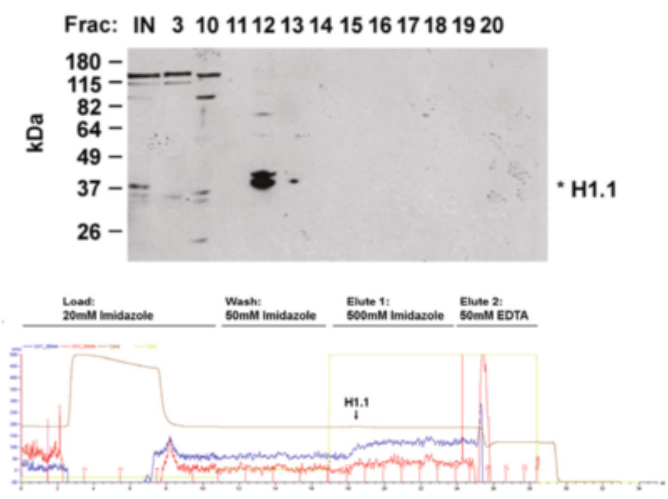

f
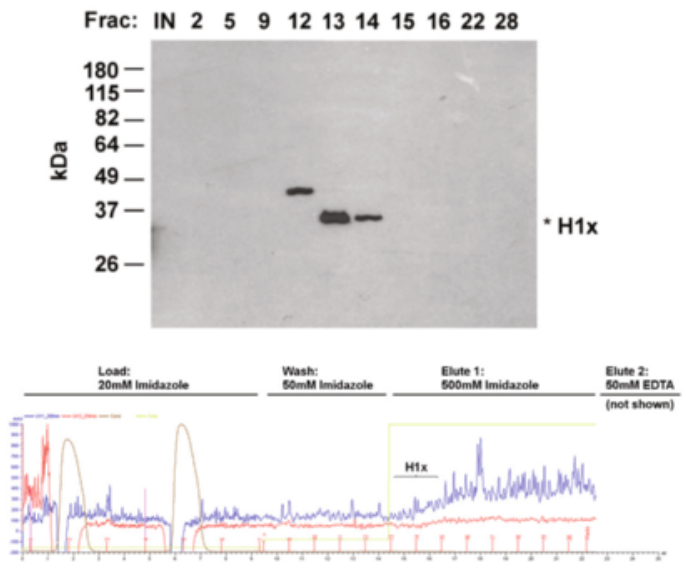

Fig. 2 Purification of H1.1, H1.2 and H1x Complexes. a-c Soluble whole cell extracts of U2OS cells expressing $6 \times$ His - tagged H1.1 (a), H1.2 (b) or H1x (c) were purified on a Mono Q column. Top panel: $1 \mathrm{ml}$ fractions were collected, resolved by SDS-PAGE gel, and immunoblotted with anti-His antibodies. Bottom panel: chromatogram showing chromatography conditions used. d-f Peaks containing $6 \times$ His - tagged H1.1 (d), H1.2 (e) or H1x (f) from Mono Q column were pooled and applied to a nickel column in loading buffer containing 20 mM imidazole, washed with $50 \mathrm{mM}$ imidazole and then eluted with $500 \mathrm{mM}$ imidazole. Top panel: $1 \mathrm{ml}$ fractions were collected, resolved by SDS-PAGE gel, and visualized by immunoblotting with anti-His antibodies. Bottom panel: chromatogram showing chromatography conditions used

each analysis, is listed in Additional file 1: Table S1. The distribution of specificities of the identified linker histone binding proteins for H1.1, H1.2 and H1x is represented by a Venn diagram in Fig. 3a. Approximately half of the proteins identified interact with more than one linker histone variant while half are specific for a single $\mathrm{H} 1$ species.
The protein list contains a large number of ribosomal proteins. Several recent proteomic studies have also found that linker histones bind to ribosomes and this interaction has been implicated in transcriptional repression [14-17]. Recent proteomic studies of linker histone binding proteins have used a fundamentally different approach where a 


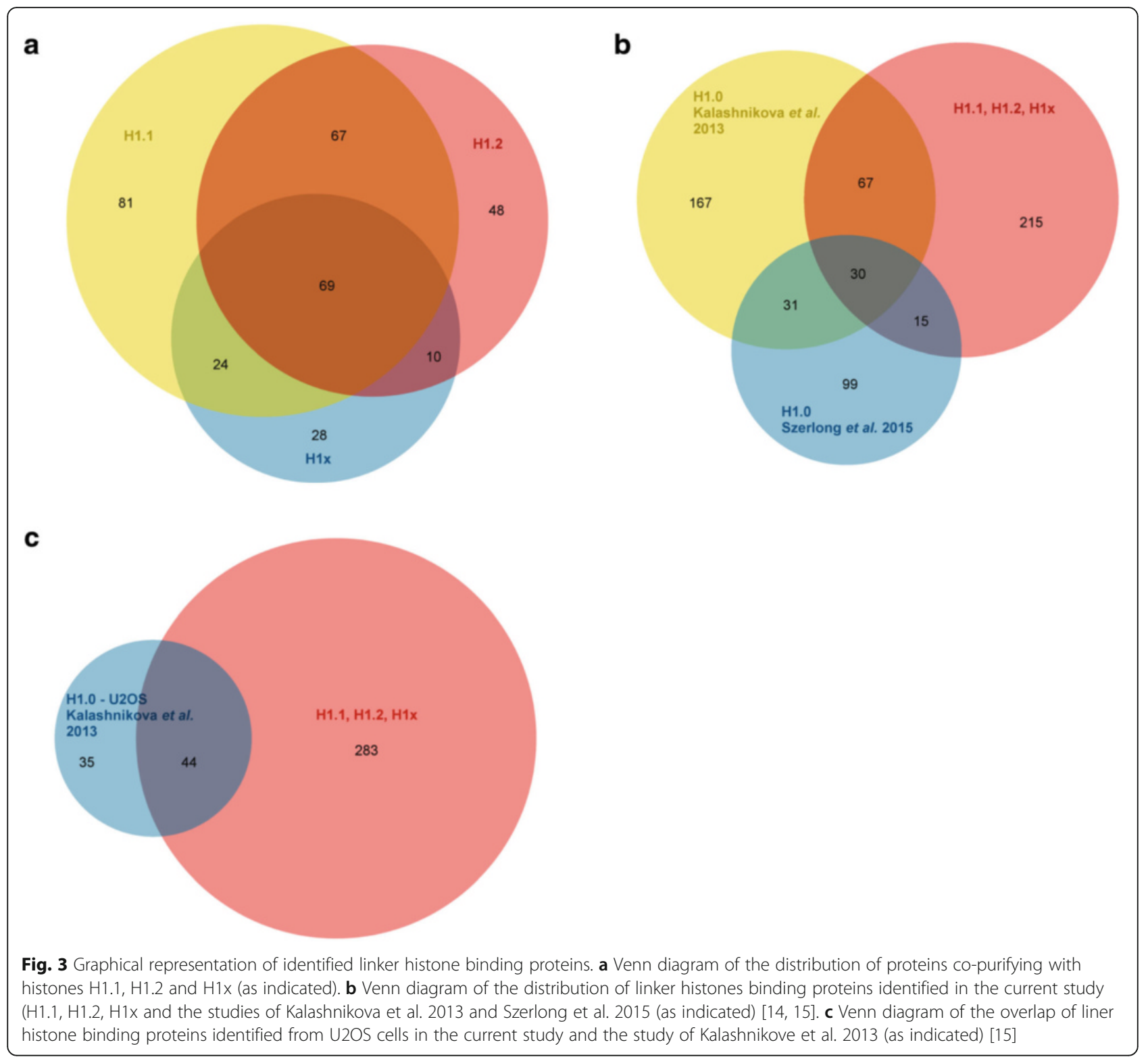

histone $\mathrm{H} 1$ variant was immobilized and incubated with nuclear or nucleolar extracts $[14,15]$. In addition to these differences in experimental approach, these studies used a different linker histone variant than those used in the current study. Despite these differences, there is significant overlap in the $\mathrm{H} 1$ interacting proteins identified. As seen in Fig. 3b, there is approximately $30 \%$ overlap in the linker histone binding proteins identified in the current study and in the previous studies. In addition, if only the linker histone binding proteins identified from the same cell line are considered (U2OS), the current study identified more than half of the linker histone binding proteins found by Kalashnikova and colleagues (Fig. 3c).

Table 1 lists all of the non-ribosomal proteins found to co-purify with the linker histones that were detected by at least 5 peptides in both of the duplicate samples (average number of peptides listed). These proteins are divided into 6 groups based on their pattern of interaction. Group 1 consists of the proteins that co-purified with all three linker histones. Group 2 proteins co-purified with the replication-dependent $\mathrm{H} 1.1$ and H1.2 but not with the replication-independent H1x. Group 3, group 4 and group 5 proteins were specifically associated with a single histone $\mathrm{H} 1$ variant (H1.1, H1.2 and $\mathrm{H} 1 \mathrm{x}$, respectively) and, as expected, each of these groups contained the corresponding $\mathrm{H} 1$ variant (proteins specifically identified in H1.1 peak 2 are indicated by an asterisk). Group 6 proteins were associated with both histone H1.1 and H1x.

The group 1 proteins included two proteins that had previously been identified as histone chaperones, nucleolin 
Table 1 Linker histone binding proteins

\begin{tabular}{|c|c|c|c|c|}
\hline PROTEIN & $\begin{array}{c}\text { H1.1 } \\
\text { (AVG \# PEPTIDES) }\end{array}$ & $\begin{array}{c}\text { H1.2 } \\
\text { (AVG \# PEPTIDES) }\end{array}$ & $\begin{array}{c}\text { H1.X } \\
\text { (AVG \# PEPTIDES) }\end{array}$ & $\begin{array}{l}\text { NEG. CONTROL } \\
\text { (AVG \# PEPTIDES) }\end{array}$ \\
\hline VIR & 70 & 37 & 21 & 10 \\
\hline SRP68 & 33 & 61 & 56 & 5 \\
\hline SRP72 & 22 & 43 & 46 & 4 \\
\hline CDK11B & 36 & 32 & 11 & 7 \\
\hline $\mathrm{YBX}_{1 *}^{*}$ & 27 & 8 & 7 & 0 \\
\hline${\mathrm{YBX} 3^{*}}^{*}$ & 21 & 10 & 6 & 0 \\
\hline WTAP & 21 & 21 & 21 & 8 \\
\hline NUCLEOLIN & 20 & 34 & 12 & 6 \\
\hline NPM1 & 19 & 11 & 7 & 0.5 \\
\hline YTDC1 & 18 & 11 & 5 & 2 \\
\hline SSRP & 15 & 4 & 7 & 1 \\
\hline ZC $3 \mathrm{H} 13$ & 13 & 5 & 7 & 1 \\
\hline CCNL1 & 12 & 3 & 3 & 0 \\
\hline UBP34 & 10 & 21 & 4 & 1 \\
\hline CCNL1 & 12 & 7 & 3 & 0 \\
\hline HAKAI & 6 & 3 & 4 & 0 \\
\hline TPR & 24 & 46 & 0 & 0 \\
\hline CHD8 & 15 & 32 & 0 & 3 \\
\hline PAF1 & 11 & 11 & 0 & 0 \\
\hline CTR9 & 10 & 9 & 0 & 0 \\
\hline CDC73 & 5 & 8 & 0 & 0 \\
\hline LEO1 & 5 & 6 & 2 & 0 \\
\hline H1.1 & 25 & 3 & 7 & 3 \\
\hline NAP1L1 & 15 & 0 & 0 & 0 \\
\hline NAP1L4 & 10 & 0 & 0 & 0 \\
\hline PABP1* & 26 & 4 & 2 & 1 \\
\hline SPT16 & 25 & 8 & 8 & 9 \\
\hline POP1* & 13 & 3 & 0 & 1 \\
\hline PABP4* & 13 & 2 & 0 & 0 \\
\hline PABP3* & 12 & 2 & 5 & 1 \\
\hline NDE1 & 11 & 2 & 1 & 4 \\
\hline TRA2B* & 10 & 2 & 1 & 0 \\
\hline UBF1 & 8 & 2 & 0 & 0 \\
\hline SET & 6 & 1 & 0 & 0 \\
\hline S3OBP & 5 & 2 & 3 & 0 \\
\hline $\mathrm{H} 1.2$ & 8 & 21 & 4 & 6 \\
\hline VPRBP & 1 & 27 & 0 & 0 \\
\hline DDB1 & 1 & 15 & 0 & 0 \\
\hline EBP2 & 0 & 15 & 0 & 0 \\
\hline TIF1B & 2 & 12 & 0 & 3 \\
\hline DDX21 & 0 & 7 & 0 & 0 \\
\hline TAF5 & 0 & 7 & 0 & 1 \\
\hline $\mathrm{CHD7}$ & 1 & 6 & 0 & 1 \\
\hline DDX50 & 1 & 5 & 0 & 0 \\
\hline H1x & 0 & 2 & 93 & 4 \\
\hline UBP15 & 2 & 0 & 15 & 1 \\
\hline |F2B3 & 0 & 0 & 10 & 0 \\
\hline ZNF16 & 11 & 2 & 5 & 0 \\
\hline $\mathrm{DCD}$ & 10 & 3 & 12 & 2 \\
\hline SRSF7 & 10 & 2 & 6 & 1 \\
\hline SRSF3 & 6 & 2 & 6 & 1 \\
\hline
\end{tabular}

Table lists the selected proteins identified by mass spectrometry associated with the linker histones H1.1, H1.2 and H1.X (color coded as indicated). Table lists the average number of peptides identified from each linker histone purification. The averages are derived from 2 to 4 replicates. * denotes proteins identified in histone H1.1 Mono-Q peak 2. $\square=$ ALL H1's (GROUP 1), $\square=$ H1.1 AND H1.2 (GROUP 2), $\square=$ H1.1 (GROUP 3), $\square=$ H1.2 (GROUP 4), $\square=\mathrm{H} 1 . \mathrm{X}($ GROUP 5), $=\mathrm{H} 1.1$ AND H1.X (GROUP 6 )

and nucleophosmin (NPM1) [18]. Nucleolin and nucleophosmin are broad specificity histone binding proteins and have been found to associate with both core and linker histones [11, 19-22]. Group 1 also included the SSRP subunit of the FACT complex, which also has been shown to interact with both core and linker histones $[15,23]$. The second subunit of FACT, Spt16, was identified as specifically interacting with histone H1.1. However, this classification was due to a high level of Spt16 peptides in the negative control sample. Therefore, it is likely that both subunits of FACT are bound to all three of the linker histone variants tested.
Group 1 also included SRP68 and SRP72. Components of the signal recognition particle, SRP68 and SRP72 have also been shown to form a heterodimeric complex distinct from the signal recognition particle. In addition to its role in translation, the SRP68/72 complex was also found to bind histone $\mathrm{H} 4$ molecules that contain arginine 3 methylation [24].

YBX1 and YBX3 also co-purified with all three linker histones. $\mathrm{Y}$ box-binding proteins bind to $\mathrm{Y}$ box consensus promoter elements and are involved in mRNA processing [25]. YBX1 was found to be recruited together with PUR $\alpha$ and histone H1.2 to the p53 target gene Bax 
in order to repress p53-induced transcription [26]. Our data indicates that YBX1 not only associates with H1 variant $\mathrm{H} 1.2$, but with $\mathrm{H} 1.1$ and $\mathrm{H} 1 \mathrm{x}$ as well. Interestingly, these $\mathrm{Y}$ box proteins were only detected in the H1.1 complex that corresponded to the second peak of H1.1 on the Mono Q column.

Five of the group 1 proteins are linked to $\mathrm{N}^{6}$-methyladenosine modification of mRNA. VIR (virilizer homolog), WTAP (Wilms Tumor Associated Protein), ZC3H13 and Hakai are all components of the WTAP complex that serves to target the METTL3 and METTL14 methyltransferases to their substrate [27-30]. In addition, YTDC1 is a YTH domain protein that can function as a reader of $\mathrm{N}^{6}$ methyladenosine [31-34].

The remaining group 1 proteins include a cyclin/cdk complex; CCNL1 and CDK11b. Linker histones are highly phosphorylated and often used as non-specific substrates in kinase assays. In fact, CDK11b has been shown to be able to phosphorylate histone $\mathrm{H} 1$ in vitro [35]. The observation that the CCNL1/CDK11b complex can be purified in association with linker histones suggests that H1s may be a specific substrate of this kinase complex. Finally, all three $\mathrm{H} 1$ variants associate with the ubiquitin hydrolase UBP34.

The group 2 proteins bind specifically to the replicationdependent $\mathrm{H} 1$ variants $\mathrm{H} 1.1$ and $\mathrm{H} 1.2$ but don't form a complex with the replication-independent variant H1x. The group 2 proteins include 4 subunits of the PAF1 complex, PAF1, CTR9, CDC73 and LEO1 [36]. The specificity of the interaction between the PAF1 complex and H1.1 and H1.2 is consistent with a recent study that showed that PAF1 co-purified with epitope tagged H1.1 and H1.2 but not with the other replication-dependent $\mathrm{H} 1$ variants $\mathrm{H} 1.3$, H1.4, H1.5 or with the replication-independent variant H1.0. The association of the PAF1 complex with H1.1 and H1.2 was shown to function with Cul4A in transcriptionassociated ubiquitylation [37].

CHD8 has previously been shown to function in transcriptional repression of p53 and $\beta$-catenin target genes through the recruitment of histone $\mathrm{H} 1[38,39]$. The proteomic data presented here suggests that the interaction between CHD8 and linker histones is variant specific.

The nuclear pore complex protein Tpr was also found to be replication-coupled $\mathrm{H} 1$ variant specific. Tpr (translocated promoter region) is a component of the nuclear pore complex (NPC), forming fibrous structures that extend into the nuclear interior [40]. Tpr is required for establishing heterochromatin exclusion zones in the vicinity of NPCs [41]. In addition to its roles in NPC architecture, Tpr is also involved in mRNA, unspliced RNA and nuclear protein export [42-44]. Depletion of Tpr induces nuclear accumulation of p53, and facilitates autophagy [45].

Proteins that specifically co-purified with histone H1.1 (group 3) included several known histone chaperones.
NapP1L1 and SET were recently shown to bind histone H1.0 in vitro $[16,46]$. NAP1L4 has not previously been demonstrated to interact with linker histones.

Group 3 contained several proteins involved in RNA metabolism. These included three poly A binding proteins, PABP1, PABP3 and PABP4, as well as the RNaseP subunit POP1 $[47,48]$. In addition, proteins involved in transcriptional regulation, NDE1, UBF1 and S30BP were also found to be specific for histone H1.1.

H1.2 specific binding partners (group 4) included DNA damage-binding protein 1 (DDB1) and protein VPRBP (also known as DDB1-CUL4-associated factor 1, DCAF1). DDB1 and VPRBP are both members of an E3 ubiquitin-protein ligase complex, named CUL4A-RBX1DDB1-DCAF1/VPRBP complex, which is responsible for methylation-dependent ubiquitylation [49]. VPRBP and DDB1 were recently shown to co-purify with both H1.1 and H1.2 along with Cul4A and the PAF1 complex [37]. The distinct properties of the PAF1 and Cul4A complex subunits in the U2OS cells suggest that the specificity of the interaction between the Cul4A complex and linker histones is subject to cell type specific regulation.

Group 4 contained two RNA helicases, DDX21 and DDX50 and the nucleolar RNA binding protein EBP2. Group 4 also contained the transcriptional regulators TAF5 and TIF1B, as well as CHD7. While CHD7 has not been shown to be associated with linker histones, these results suggest that it may function in a manner analogous to CHD8.

Only two proteins were found to be exclusive binding partners of H1x (group 6). These were ubiquitin carboxylterminal hydrolase 15 (USP15) and insulin-like growth factor 2 mRNA-binding protein 3 (IGF2BP3). USP15 is a deubiquitinating enzyme that can bind to ubiquitinated $\mathrm{H} 2 \mathrm{~A} / \mathrm{H} 2 \mathrm{~B}$ dimers, and removes ubiquitin from ubiquitinated H2B that are not in nucleosomes [50]. IGFBP3 belongs to a family of three IGF-II mRNA-binding proteins that can bind to the 5' UTR of the insulin-like growth factor II leader 3 mRNA and regulate the translation of insulin-like growth factor II during late mammalian development [51]. Interactions between USP15 and IGFBP3 and linker histones have not been reported previously.

Group 6 is an eclectic collection of proteins that copurified with both H1.1 and H1x. This group includes the RNA binding proteins SRSF3 and SRSF7, the zinc finger protein ZNF16 and the anti-microbial protein dermcidin.

\section{Interactions between nucleoprotein $\mathrm{Tpr}$ and $\mathrm{H} 1$ variants}

The proteomics data clearly demonstrate that linker histones participate in a complex set of interactions that display varying degrees of specificity for the $\mathrm{H} 1$ variants. To explore in more detail the distinction between replication-dependent (H1.1 and H1.2) and replicationindependent $(\mathrm{H} 1 \mathrm{x}) \mathrm{H} 1$ variants, we examined whether 
the specificity observed for replication-dependent H1.1 and H1.2 displayed by Tpr was a reflection of a specific in vivo connection between $\mathrm{Tpr}$ and replicationdependent linker histones. Unlike the PAF-1 complex and CHD8, which were also identified in the H1.1 and H1.2 complexes but not in the H1x complex (Table 1), Tpr has not been previously shown to interact with linker histones. To confirm the potential for interactions between $\mathrm{Tpr}$ and $\mathrm{H} 1$ variants in vivo, we resolved soluble whole cell extracts of U2OS cells expressing H1.1, H1.2 or H1x by size exclusion chromatography (Fig. 4). In all three cases, the peaks of $\mathrm{H} 1$ variants overlapped with the Tpr peak in a very high molecular weight complex (Fraction 9-10 in Fig. 4a, Fraction 9 in Fig. 4b, and Fraction $8-10$ in Fig. 4c). These large complexes are likely due to other proteins associated with $\mathrm{Tpr}$ and/or $\mathrm{H} 1$ variants through direct or indirect interactions. The overlapping elution profiles of the linker histones and $\mathrm{Tpr}$ is consistent with the possibility that Tpr can form complexes with the linker histones in vivo but does not provide biochemical evidence for specific association of $\mathrm{Tpr}$ with the replication-dependent linker histones. Recprical co-immunopreciptations were also attempted to obtain additional evidence for for the specific interactions between Tpr and linker histones. However, currently available anti-Tpr antibodies were efficient for the immunopreciptation of Tpr and its associated proteins.

\section{Tpr knockdown specifically reduces replication-} dependent $\mathrm{H} 1$ variant levels via protein degradation To determine whether the observed interactions between $\mathrm{Tpr}$ and replication-dependent linker histones are functionally relevant, we treated U2OS cells expressing $6 \times$ His-tagged H1.1, H1.2 or H1x with Tpr-targeting siRNA

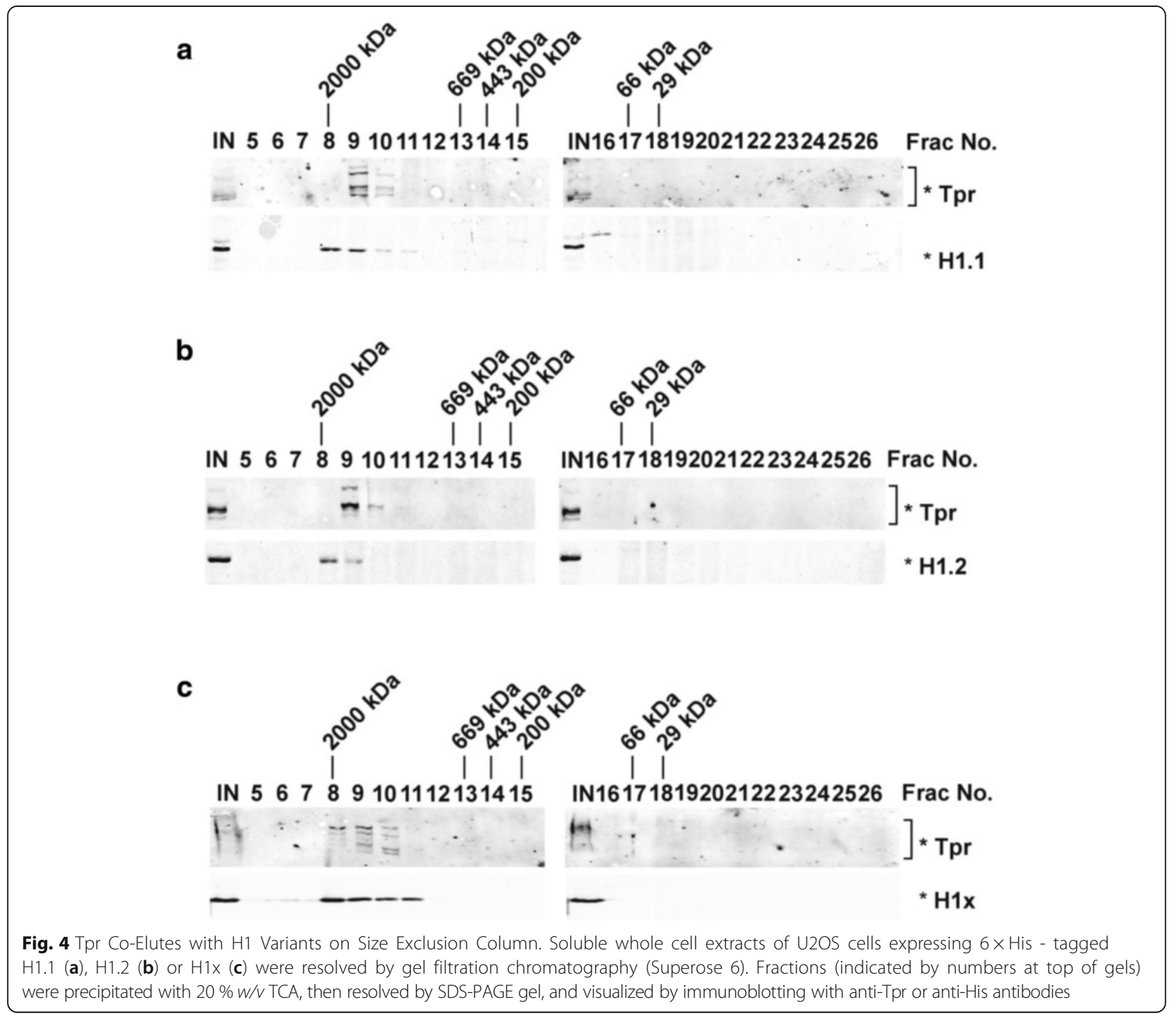


in order to knockdown the expression of Tpr proteins. Surprisingly, we found that siTpr treated cells, which had significantly reduced $\mathrm{Tpr}$ immunofluorescence signals, also showed reduced immunofluorescence signals of $6 \times$ His-tagged replication-dependent variants $\mathrm{H} 1.1$ and H1.2, but not replication-independent variant H1x (Fig. 5a). In both control siRNA and Tpr siRNA treated cells, all three $\mathrm{H} 1$ variants were localized within the nucleus, indicating that the loss of Tpr did not disrupt the nuclear distribution of histone H1. The fluorescence intensities of the signals for Tpr and the $\mathrm{H} 1$ variants, relative to the signal for DAPI, were quantitated and plotted (Fig. 5b). Based on a linear regression analysis of the data there was a clear positive correlation between the level of Tpr and the levels of histone H1.1 and H1.2 ( $r=0.83$ and 0.89 , respectively) while there was no correlation between the level of $\mathrm{Tpr}$ and the level of $\mathrm{H} 1 \mathrm{x}(r=0.17)$. Consistent with the immunofluorescence data, we also observed reduced H1.1 and H1.2 protein levels in Tpr siRNA treated cells on western blots; however $\mathrm{H} 1 \mathrm{x}$ protein levels were not affected (Fig. 5c).

The reduction in H1.1 and H1.2 levels in Tpr knockdown cells could have been a result of a decrease in mRNA abundance or by protein destabilization. In order to investigate the effect of Tpr depletion on histone H1 gene expression, we performed quantitative real-time PCR analysis on the mRNA levels of H1.1, H1.2, and $\mathrm{H} 1 \mathrm{x}$ in U2OS cells treated with either control siRNA or Tpr siRNA. Tpr knockdown did not cause any significant decrease in the mRNA levels of any of the three $\mathrm{H} 1$ variants (Fig. 6a and b).

To test whether Tpr is required for histone H1.1 and H1.2 protein stability, we treated U2OS cells with MG132, which is a cell permeable proteasome inhibitor.

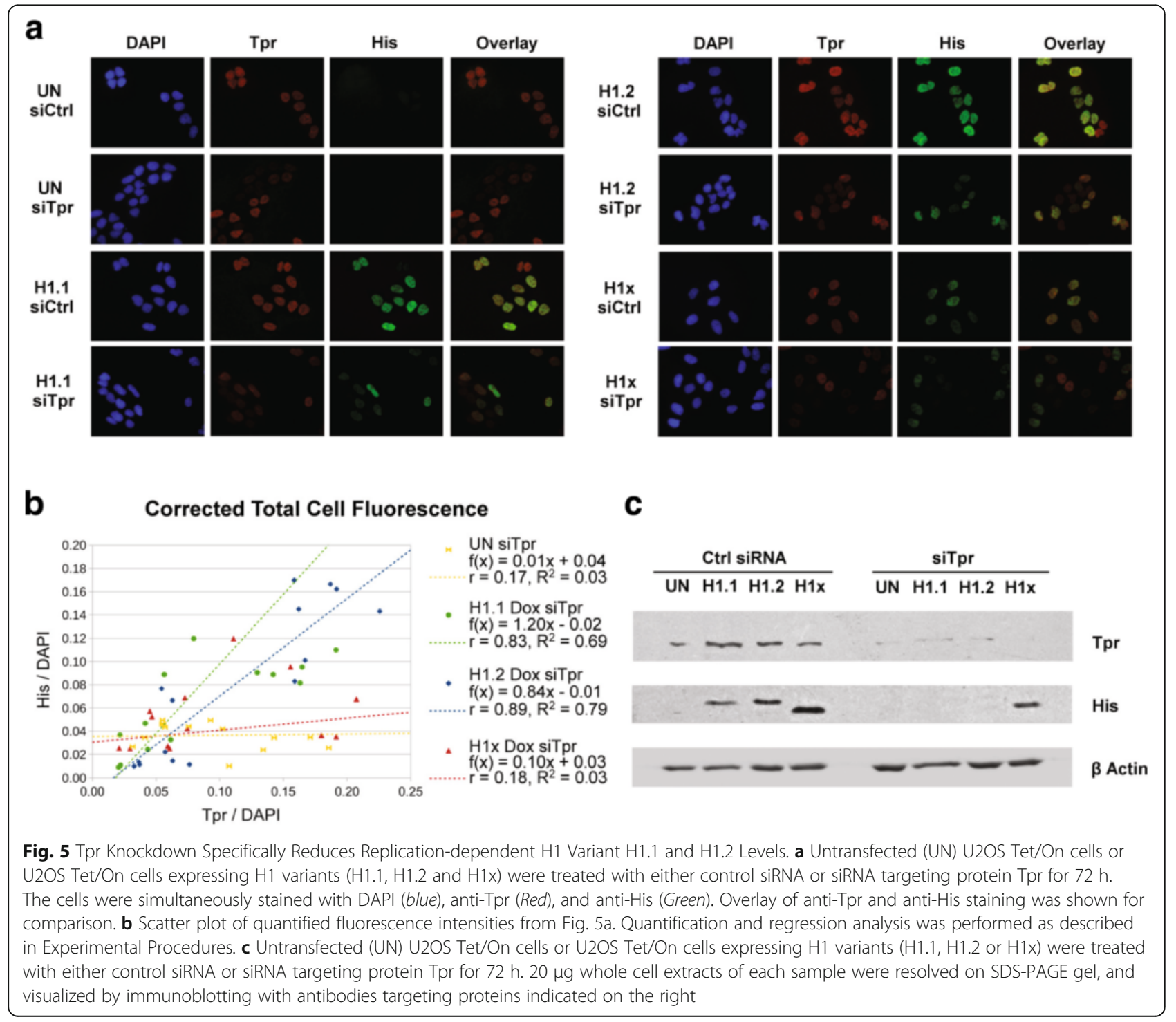


In the presence of MG132, H1.1 and H1.2 protein levels were restored in Tpr siRNA treated cells to levels comparable to those of control siRNA treated cells (Fig. 6c). Immunofluorescence microscopy of MG132 treated cells also confirmed this rescue of $\mathrm{H} 1.1$ and $\mathrm{H} 1.2$ protein levels (Fig. 6d). Quantitation of the immunofluorescence data indicated a clear decrease in the correlation of the levels of $\mathrm{Tpr}$ and histones $\mathrm{H} 1.1$ and $\mathrm{H} 1.2$ with an increase in the number of cells with a low level of Tpr that maintain a high level of the replication-dependent linker histones (Fig. 6e). It is important to note that in MG132 treated cells all H1 variants were still localized within the nucleus, indicating that loss of Tpr did not cause replication-dependent $\mathrm{H} 1$ proteins to accumulate in the cytosol suggesting that $\mathrm{Tpr}$ is not required for the nuclear import of replication-dependent linker histones. These results suggest that the specific interaction between $\mathrm{Tpr}$ and replication-dependent histone $\mathrm{H} 1$ variants detected biochemically is a reflection of a specific in vivo interaction. Further, the interaction between $\mathrm{Tpr}$ and histones $\mathrm{H} 1.1$ and $\mathrm{H} 1.2$ is critical to maintain the proper abundance of these linker histones.

\section{Discussion}

There is accumulated evidence indicating functional differentiation among linker histone variants. The abundance of $\mathrm{H} 1$ variants fluctuates in diverse cell types and at development stages $[6,52]$. Their ability to condense chromatin also varies (reviewed in [53]). In addition, the $\mathrm{H} 1$ variants can engage in a wide range of different proteinprotein interactions (reviewed in [16, 54]). Several previous proteomic studies focused on the characterization of the linker histone variants $\mathrm{H} 1.0$ and $\mathrm{H} 1.2$ interaction networks, however the comparison of replicationdependent and replication-independent $\mathrm{H} 1$ variants is still lacking [14, 15, 37]. In order to understand how replication-dependent and replication-independent H1 variants carry out differentiated functions through protein-protein interactions, we purified protein complexes containing $6 \times$ His-tagged replication-dependent H1 variants $\mathrm{H} 1.1$ and $\mathrm{H} 1.2$, or replication-independent variant $\mathrm{H} 1 \mathrm{x}$, and identified their binding partners using mass spectrometric analysis.

Broadly speaking, our proteomic characterization of linker histones binding proteins identifies four groups of proteins that interact with linker histones. We used soluble whole cell extracts as the starting material for the $\mathrm{H} 1$ purifications to facilitate the identification of histone chaperones that would regulate the transport and assembly of the linker histones. Indeed, a significant fraction of the $\mathrm{H} 1$ interacting proteins are previously known histonebinding proteins. While many of these proteins have primarily been characterized in the context their functions as core histone chaperones, it will be interesting to determine how they also impact linker histone dynamics.

The well-characterized function of linker histones in the regulation of transcription is reflected in the abundance of transcription factors identified as linker histone binding proteins. The observation that some transcription factors are highly specific for a single histone $\mathrm{H} 1$ variant suggests that some of the unique functions of the linker histones may be mediated by protein-protein interactions that regulate specific subsets of genes.

The other two groups of proteins were related to RNA biology. The largest groups of interacting factors were ribosomal proteins. The interaction of linker histones with ribosomes has been observed both in vitro and in vivo and has been implicated in transcriptional repression $[14,15,17]$. We also identified a number of proteins involved in RNA metabolism including RNA binding proteins and RNA helicases. Surprisingly, multiple members of the WTAP complex, which is required for a significant fraction of the $\mathrm{N}^{6}$-methyladenosine modification in the cell, as well as the $\mathrm{N}^{6}$-methyladenosine reader protein YTDC1 were associated with all three H1 variants [28]. Together, these results suggest the intriguing possibility that linker histones may provide an important link between chromatin structure and RNA metabolism.

Surprisingly, NASP (nuclear antigenic sperm protein) was not found to associate with any of the histone H1 variants in the present study and has not been identified in the recent proteomic analyses of in vivo linker histone complexes [16, 26, 37]. NASP was one of the first proteins proposed to be a linker histone chaperone and, in fact, can bind linker histones with nM affinity in vitro [55-57]. The inability to identify NASP as linker histone-associated protein in multiple studies suggests a number of possibilities. NASP may not interact with linker histones to a significant extent despite the demonstrated in vitro affinity. Alternatively, NASP may interact in vivo with only a subset of the linker histone variants that have not yet been examined by proteomic methods.

In comparing the proteins that co-purified with each of the $\mathrm{H} 1$ variants, we found that the three $\mathrm{H} 1$ variants had shared binding partners that were identified in earlier studies, such as nucleophosmin, nucleolin and FACT complex subunits SPT16 and SSRP1, nucleolin, nucleophosmin (NPM1) and Y box-binding proteins YB1, YB2 and YB3. These H1-associating proteins may contribute to the common functions of $\mathrm{H} 1$ variants. Importantly, we identified shared components found in the replicationdependent $\mathrm{H} 1$ variant complexes that were not associated replication-independent $\mathrm{H} 1$ variants. These factors include the PAF1 complex, CHD8 and nucleoprotein Tpr. The recent study from Kim and colleagues demonstrated that the PAF1 complex is not associated with histone 


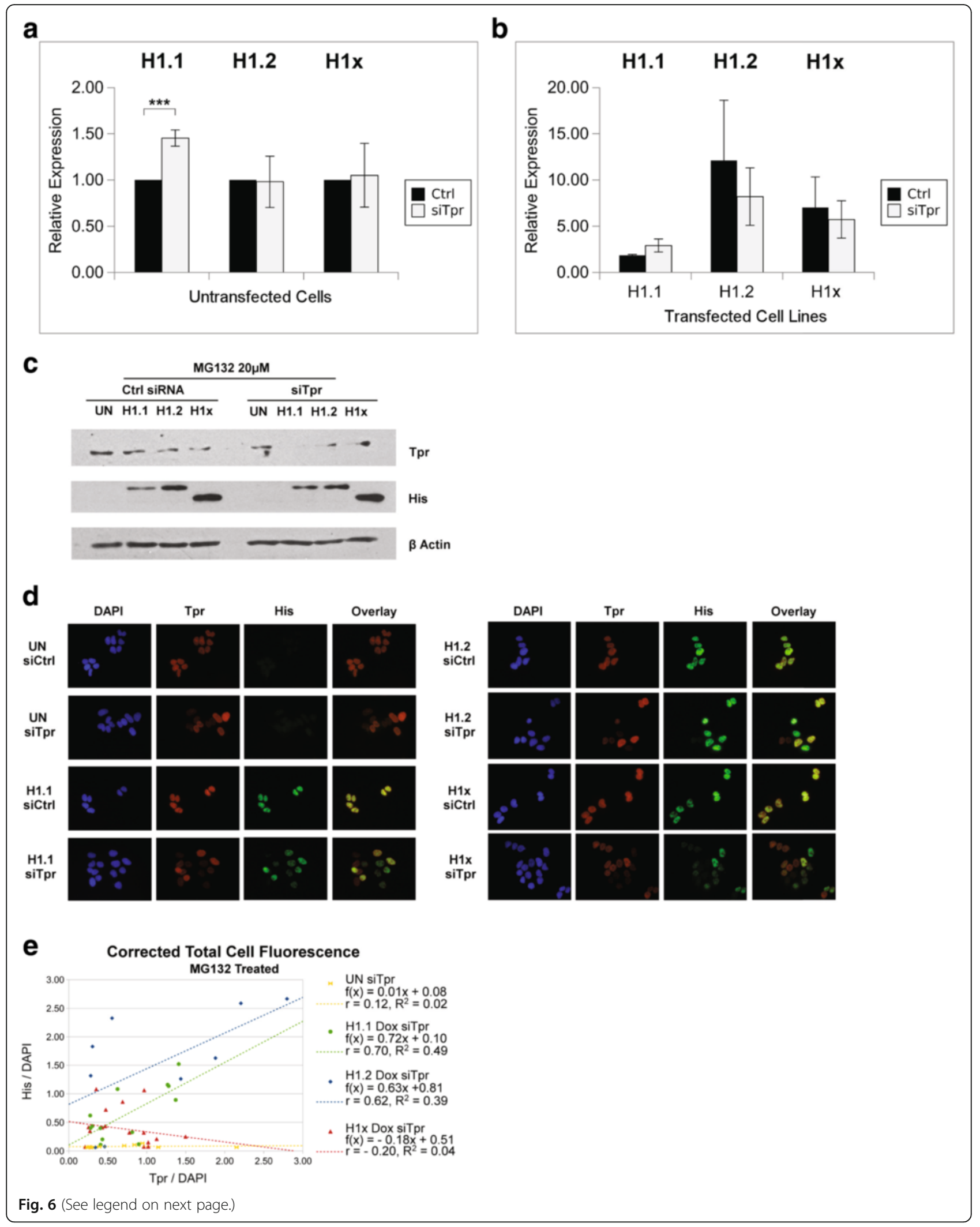




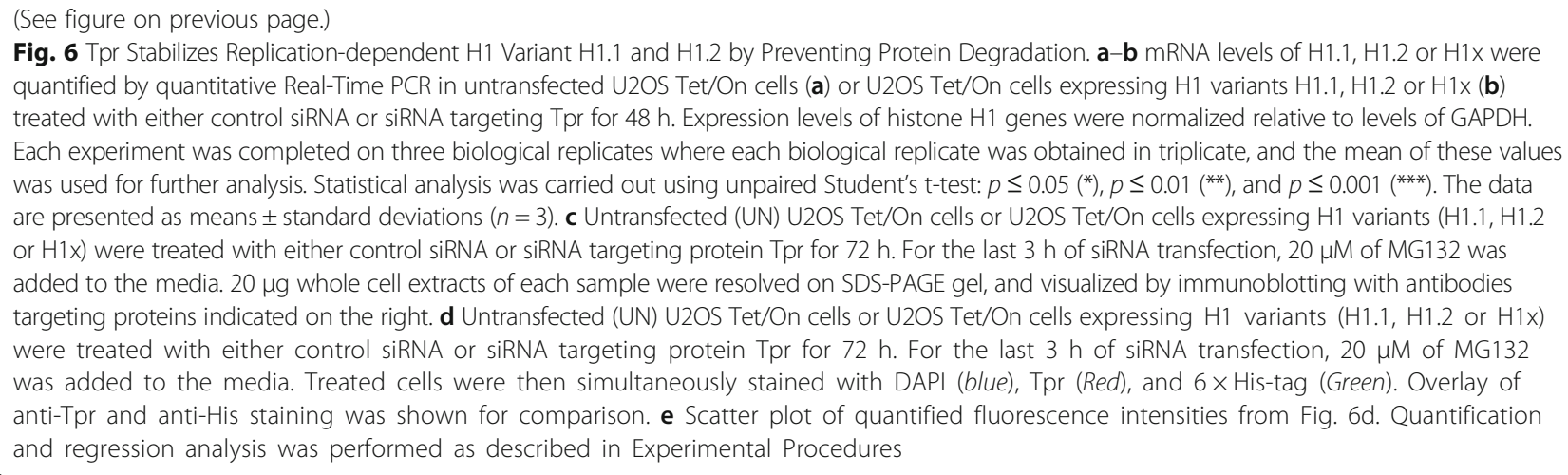

H1.0 consistent with the specificity of this complex for replication-dependent linker histones [37]. These exclusive protein-protein interactions may be crucial for mediating cell cycle-dependent functions of $\mathrm{H} 1$ variants.

The interactions of the PAF-1 complex and CHD8 with linker histones have demonstrated functions in transcriptional regulation [37-39]. However, a link between Tpr and linker histones has not previously been identified. Our analysis of Tpr siRNA knockdown cells supports the proteomic data that indicated that Tpr engages in specific interactions as Tpr knockdown reduced the levels of replication-dependent $\mathrm{H} 1$ variants $\mathrm{H} 1.1$ and $\mathrm{H1} 1.2$, but not replication-dependent $\mathrm{H} 1$ variant H1x. Future studies will determine whether Tpr also interacts with the remaining replication-dependent linker histones, H1.3, H1.4 and H1.5 or, whether, like the PAF1 complex, it is specific for H1.1 and H1.2.

While Tpr is required for the stability of histones H1.1 and H1.2, the functional significance of their interaction is not clear. As Tpr is a component of the nuclear pore complex, the most straightforward model is that Tpr is specifically involved in the nuclear import of replicationdependent linker histones. This model predicts that if the levels of H1.1 and H1.2 were restored in cells lacking Tpr that the histones would accumulate in the cytoplasm. However, when the Tpr siRNA knockdown was performed in the presence of the proteasome inhibitor MG132, we observed no cytoplasmic accumulation of H1.1 and H1.2.

A second possibility is that Tpr can function as a histone chaperone that participates in the targeting of replication-dependent linker histones to sites of chromatin assembly. Indeed, Tpr contains a region nears the $\mathrm{COOH}$-terminus that is highly enriched in aspartic acid and glutamic acid as is observed in many histone chaperones. In addition, a recent proteomic analysis of nascent chromatin structure identified $\mathrm{Tpr}$ as a chromatinassociated protein [58].

Another potential function for the interaction of Tpr with histones H1.1 and H1.2 may be related to involvement of
Tpr in the formation of heterochromatin exclusion zones (HEZs) around nuclear pores. While heterochromatin localizes near the nuclear envelope, regions near the nuclear pores are devoid of heterochromatin through the formation of Tpr-dependent HEZs [41]. The interaction between $\mathrm{Tpr}$ and replication-dependent $\mathrm{H} 1$ variants may be important for the maintenance of HEZs. Tpr may stabilize and preserve $\mathrm{H} 1$ variants with minimal DNA compaction abilities, such as H1.1 and H1.2, which establishes a basal level of chromatin packaging around HEZs, while keeping out $\mathrm{H} 1$ variants that promote strong condensation, such as H1x. To test this hypothesis, it would be interesting to investigate the interactions between $\mathrm{Tpr}$ and other $\mathrm{H} 1$ variants with higher affinity and/or higher capacity for the compaction of nucleosomes, such as H1.3 and H1.4 (Reviewed in [53]).

\section{Conclusions}

We have isolated and analyzed the soluble forms of the replication-dependent linker histones H1.1 and H1.2 and the replication-independent linker histone H1x. These linker histones interact with both a common group of proteins and with variant-specific interacting proteins. One protein that is specifically associated with $\mathrm{H} 1.1$ and H1.2 is nuclear pore complex protein Tpr. Tpr was not required for the nuclear import of histones H1.1 and H1.2. However, knockdown of Tpr expression resulted in a specific decrease in protein stability of the replicationdependent linker histones.

\section{Methods}

\section{Antibodies and other materials}

Sources of antibody employed are as follows: anti-His.M8 from Thermo Fisher Scientific was used for western blots; anti-His $_{6}$ from Roche was used for immunofluorescence microscopy; anti-Tpr from Abcam. Control siRNA (sc-37007) and siRNA targeting Tpr (sc-45343) was purchased from Santa Cruz Biotech. 


\section{Plasmid construction}

The human Ultimate ORF of histone H1.1 (IOH35288), H1.2 (IOH5275), and H1x (IOH3417) (Thermo Fisher Scientific) were inserted into mammalian expression vector pT-Rex-DEST31 (Thermo Fisher Scientific), which adds a $6 \times$ His-tag at the $\mathrm{NH}_{2}$-terminus. The resulting constructs were transferred into DH10B E. coli strain for production.

\section{Cell culture and transfections}

Tetracycline-inducible human osteosarcoma cell line U2OS (kind gift from Dr. Dan Schoenberg) was grown in McCoy's 5A media supplemented with $10 \%(v / v)$ fetal bovine serum, $50 \mathrm{U} / \mathrm{ml}$ penicillin, $50 \mathrm{mg} / \mathrm{ml}$ streptomycin, and $1 \%$ L-glutamate (Sigma) at $37^{\circ} \mathrm{C}$ in $5 \% \mathrm{CO}_{2}$ supply. The U2OS cells were transfected with pT-Rex-DEST31 plasmids carrying H1.1, H1.2 or H1x using X-tremeGENE HP DNA transfection reagent (Roche) following the manufacturer's instruction. Transfected clones were selected against $200 \mathrm{mg} / \mathrm{ml} \mathrm{G418}$ and $10 \mathrm{mg} / \mathrm{ml}$ blasticidin (Gibco, Thermo Fisher Scientific). Stable clones were induced by $1 \mu \mathrm{g} / \mathrm{ml}$ doxycycline (Sigma) for $48 \mathrm{~h}$. The expression of $6 \times$ His-tagged $\mathrm{H} 1$ variants was confirmed by western blot.

\section{Cell fractionation}

Cytosolic and nuclear extracts were prepared from U2OS cells as previously described [59]. The resulting extracts were resolved on SDS-PAGE gels and visualized on western blots.

\section{Histone extractions}

Total histones were prepared from U2OS cells as previously described [60]. The resulting histone pellets were resuspended in DN (300) buffer ( $300 \mathrm{mM} \mathrm{NaCl}, 25 \mathrm{mM}$ Tris pH 7.0, $0.1 \mathrm{mM}$ EDTA, $10 \%$ glycerol, and $0.5 \mathrm{mM}$ phenyl methyl sulfonate fluoride), and resolved on $18 \%$ SDS PAGE gels. Linker histones isolated from chicken erythrocyte nuclei were also loaded in the gels as controls [56].

\section{Micrococcal nuclease digestion assays}

$1 \times 10^{7}$ U2OS cells were collected and washed with cold PBS, and incubated in lysis buffer (300 mM HEPES $\mathrm{pH} 7.5,60 \mathrm{mM} \mathrm{KCl}, 300 \mathrm{mM}$ sucrose, $5 \mathrm{mM} \mathrm{K}_{2} \mathrm{HPO}_{4}$, $5 \mathrm{mM} \mathrm{MgCl}_{2}, 2 \mathrm{mM}$ EDTA, and $0.5 \%$ Triton X-100) for $5 \mathrm{~min}$ on ice. The cells were then broken with 7 gentle strokes in a type B Dounce homogenizer. Nuclei were pelleted by centrifuging at $120 \times \mathrm{g}$ for $10 \mathrm{~min}$. The pelleted nuclei were washed with $1 \mathrm{ml}$ MNase digestion buffer (10 mM Tris pH7.5, $15 \mathrm{mM} \mathrm{NaCl}, 1 \mathrm{mM} \mathrm{CaCl}$, $60 \mathrm{mM} \mathrm{KCl}$, and $0.2 \mathrm{mM}$ phenyl methyl sulfonate fluoride), resuspended in $1 \mathrm{ml}$ MNase digestion buffer, and digested with $0.2 \mathrm{U} / \mathrm{ml}$ (Sigma units) of MNase at $37{ }^{\circ} \mathrm{C}$ for various lengths of time. Digestions were stopped with
$10 \mathrm{mM}$ EDTA followed by incubation with $0.1 \mathrm{mg} / \mathrm{ml}$ proteinase $\mathrm{K}$ at $37{ }^{\circ} \mathrm{C}$ for $5 \mathrm{~min}$. The resulting DNA samples were isolated using phenol extraction and ethanol precipitation, and resolved on $1 \%$ agarose gel [61].

\section{Protein expression and purification}

U2OS cells with $6 \times$ His-tagged H1 inserts were induced by $1 \mu \mathrm{g} / \mathrm{ml}$ doxycycline (Sigma). After $48 \mathrm{~h}$, cells were harvested, washed with PBS, and lysed with NP40 lysis buffer $(150 \mathrm{mM} \mathrm{NaCl}, 50 \mathrm{mM}$ Tris $\mathrm{pH} 7.5,10 \%$ Glycerol, $0.75 \%$ NP40) containing EDTA-free protease inhibitor cocktail (Roche) and $0.5 \mathrm{mM}$ phenyl methyl sulfonate fluoride. The resulting whole cell extracts were applied to a Mono Q 5/50 GL column (GE Healthcare Life Sciences). Proteins were eluted with a $\mathrm{NaCl}$ gradient from $50 \mathrm{mM}$ to $500 \mathrm{mM}$ in 15 column volumes, then $1 \mathrm{M}$ for 5 column volumes. Fractions containing eluted $6 \times$ His-tagged $\mathrm{H} 1$ variants were pooled, desalted on desalting columns (GE Healthcare Life Sciences), and then applied to an HiTrap Chelating HP Column $(1 \mathrm{ml}$, GE Healthcare Life Sciences) charged with $\mathrm{Ni}^{2+}$. The column was then washed extensively with NP40 lysis buffer containing $50 \mathrm{mM}$ imidazole. Bound proteins were eluted with NP40 lysis buffer containing $500 \mathrm{mM}$ imidazole. Fractions were collected and resolved on western blots.

\section{Mass spectrometry}

Tryptic peptides were desalted online using a $\mu$-precolumn

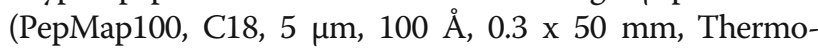
Fisher, Waltham, MA, USA) and separated based on hydrophobicity at a flow rate of $2 \mu \mathrm{L} / \mathrm{min}(\mathrm{C} 18 \mathrm{Aq}, 5 \mu \mathrm{m}, 300 \AA$ $0.2 \times 150 \mathrm{~mm}$, Michrom Bioresources Inc., Auburn, CA, USA). Peptides were introduced into a ThermoFisher LTQ Orbitrap XL mass spectrometer (ThermoFisher, Waltham, MA, USA) with the aid of micro/nanospray ionization source (Michrom Bioresources Inc., Auburn, CA, USA). Mobile phase A (MPA) consisted of HPLC water with $0.1 \% v / v$ formic acid (J.T. Baker, Center Valley, PA, USA) and mobile phase B (MPB) consisted of ACN (EMD Millipore, Billerica, MA, USA) with $0.1 \% \mathrm{v} / \mathrm{v}$ formic acid. The HPLC gradient was ramped from 2 to $40 \%$ MPB from 5 to $155 \mathrm{~min}$, followed by a high organic wash and column equilibration period. The heated capillary temperature and electrospray voltage were set to $175^{\circ} \mathrm{C}$ and $2.0 \mathrm{kV}$. The top 5 molecular ions $(2+/ 3+$ charges $)$ were selected for CID fragmentation in a data-dependent fashion. Molecular ions were analyzed in the Orbitrap (AGC:1000 K ions; $60 \mathrm{~K}$ mass resolution; $300 \mathrm{~ms}$ max injection time, 1 microscan, precursor scan enabled). Molecular ions were selected and subjected to CID fragmentation in the linear ion trap (NCE: $35 \%$, AGC: $10 \mathrm{~K}$ ions; $300 \mathrm{~ms}$ max injection time). Dynamic exclusion parameters were enabled (30s \pm $25 \mathrm{ppm}$, repeat count:1). Protein identifications were determined using the MassMatrix search engine ( $v$ 2.4.2) and 
the complete, reviewed Swiss-Prot entries from UniProt (taxon:9606, 20,258 entries, July 2013) [62-65]. Search parameters included a maximum of two trypsin missed cleavages, molecular ion tolerance of $\pm 20 \mathrm{ppm}$ and a fragment ion tolerance of $\pm 0.8 \mathrm{Da}$. The false discovery rate (FDR) was estimated using a target-decoy strategy. Final protein identifications and spectral counts were harmonized using an in-house python application [66]. Protein identification from this harmonized protein list, were retained based on an FDR threshold of $5 \%$ where each protein consisted of at least two unique peptide matches.

\section{Size-exclusion chromatography of $\mathrm{H} 1$ complexes}

Whole cell extracts of U2OS cells expressing $6 \times$ Histagged $\mathrm{H} 1$ variants were applied to a Superose 6 10/300 GL column (GE Healthcare Life Sciences). The column was washed with 1.5 column volumes of NP40 lysis buffer. Proteins in each collected fraction were precipitated with $20 \% w / v$ TCA, then resolved and visualized on western blots.

\section{Immunofluorescence microscopy}

U2OS cells seeded on cover slips were fixed in $4 \%$ paraformaldehyde for $20 \mathrm{~min}$ at room temperature and then washed with PBS. The washed cells were permeabilized with $0.5 \%$ Triton X-100 in PBS for 15 min, then washed with PBS three times, and blocked with blocking buffer ( $1 \%$ bovine serum albumin and $0.3 \%$ Triton X-100 in PBS) for $1 \mathrm{~h}$. After blocking, the cells were incubated with primary antibodies diluted in blocking buffer overnight followed by three washes in PBST, and incubated with secondary antibodies for $1 \mathrm{~h}$. Then the cover slips with cells were washed three times in PBS, and mounted onto microscope slides with Vectashield mounting serum containing DAPI (Vector Laboratories). The slides were examined using Axioskop 40 microscope. Immunofluorescence pictures were taken with an Axiocam HRC camera and processed in Zen 2 Pro software.

\section{Quantification and analysis of immunofluorescence}

Corrected total cell fluorescence (CTCF) was quantified using ImageJ as previously described [67]. CTCF of antiTpr and anti-His ${ }_{6}$ staining were standardized against CTCF of DAPI staining. Regression analysis was carried out using Microsoft Excel built-in statistical functions.

\section{Quantitative real-time PCR analysis}

RNAs were extracted from U2OS cells using Trizol reagent (Thermo Fisher Scientific) following the manufacturer's instructions. The resulting RNAs were used to prepare cDNAs using High Capacity cDNA Reverse Transcription Kits (Applied Biosystems) following the manufacturer's instruction. Levels of gene expression were measured using TaqMan Gene Expression Assays (Applied Biosystems, Assay IDs as follows: H1.1 - Hs00271225_s1, H1.2 - Hs00271185_s1, H1x - Hs00366688_s1, and GAPDH - Hs02758991_g1), TagMan Universal PCR Master Mix (Applied Biosystems) and the ABI 7300 sequence detector as previously described [68]. Expression levels of histone $\mathrm{H} 1$ genes were normalized relative to levels of GAPDH. Each experiment was completed on three biological replicates where each biological replicate was obtained in triplicate, and the mean of these values was used for further analysis. Statistical analysis was carried out using unpaired Student's t-test: $p \leq 0.05$ $(*), p \leq 0.01(* *)$, and $p \leq 0.001(* * *)$.

\section{Additional file}

Additional file 1: Table S1. Protein identification report for $\mathrm{H} 1$ variant associating proteins. The number of unique peptides determined by mass spectrometry are given for each protein. Mock purification sample from U2OS Tet/On cells without $\mathrm{H} 1$ vector insert was used as negative control. Two technical replicates were analyzed for each $\mathrm{H} 1$ variant sample. Four technical replicates were analyzed for the negative control. (XLSX $67 \mathrm{~kb})$

\section{Acknowledgements}

We would like to thank Dr. Dan Schoenberg for the gift of Tet-inducible u2OS cells.

\section{Funding}

This work was supported by a grant from the National Institutes of Health (GM062970 to M.R.P.).

\section{Availability of data and materials}

All data generated or analysed during this study are included in this published article [and its Additional file].

\section{Authors' contributions}

PZ, OEB, MAF and MRP designed experiments. PZ and OEB performed experiments. PZ, OEB, MAF and MRP analyzed data. PZ, OEB, MAF and MRP wrote the manuscript. All authors read and approved the final manuscript.

\section{Competing interest}

The authors declare that they have no competing interests.

Consent for publication

Not applicable.

Ethics approval and consent to participate

No human subjects or animals were used in this study.

\section{Author details}

'Department of Biological Chemistry and Pharmacology, The Ohio State University, Columbus, OH 43210, USA. ²Department of Cancer Biology and Genetics, The Ohio State University, Columbus, OH 43210, USA.

Received: 11 August 2016 Accepted: 20 September 2016 Published online: 01 October 2016

\section{References}

1. Tremethick DJ. Higher-order structures of chromatin: the elusive $30 \mathrm{~nm}$ fiber. Cell. 2007;128:651-4.

2. Thomas JO, Stott K. H1 and HMGB1: modulators of chromatin structure. Biochem Soc Trans. 2012;40:341-6.

3. Happel N, Doenecke D. Histone $\mathrm{H} 1$ and its isoforms: contribution to chromatin structure and function. Gene. 2009;431:1-12. 
4. Fan Y, Nikitina T, Morin-Kensicki EM, Zhao J, Magnuson TR, Woodcock CL, Skoultchi Al. H1 linker histones are essential for mouse development and affect nucleosome spacing in vivo. Mol Cell Biol. 2003;23:4559-72.

5. Sancho $M$, Diani $E$, Beato $M$, Jordan $A$. Depletion of human histone $H 1$ variants uncovers specific roles in gene expression and cell growth. PLoS Genet. 2008:4:e1000227.

6. Terme JM, Sese B, Millan-Arino L, Mayor R, Izpisua Belmonte JC, Barrero MJ, Jordan A. Histone $\mathrm{H} 1$ variants are differentially expressed and incorporated into chromatin during differentiation and reprogramming to pluripotency. J Biol Chem. 2011;286:35347-57.

7. Campos El, Fillingham J, Li G, Zheng H, Voigt P, Kuo WH, Seepany H, Gao Z, Day LA, Greenblatt JF, Reinberg D. The program for processing newly synthesized histones H3.1 and H4. Nat Struct Mol Biol. 2010;17:1343-51.

8. Tagami H, Ray-Gallet D, Almouzni G, Nakatani Y. Histone H3.1 and H3.3 complexes mediate nucleosome assembly pathways dependent or independent of DNA synthesis. Cell. 2004;116:51-61.

9. Shintomi K, Iwabuchi M, Saeki H, Ura K, Kishimoto T, Ohsumi K. Nucleosome assembly protein-1 is a linker histone chaperone in Xenopus eggs. Proc Natl Acad Sci U S A. 2005;102:8210-5.

10. Richardson RT, Alekseev OM, Grossman G, Widgren EE, Thresher R, Wagne EJ, Sullivan KD, Marzluff WF, O'Rand MG. Nuclear autoantigenic sperm protein (NASP), a linker histone chaperone that is required for cell proliferation. J Biol Chem. 2006;281:21526-34.

11. Gadad SS, Senapati P, Syed SH, Rajan RE, Shandilya J, Swaminathan V, Chatterjee S, Colombo E, Dimitrov S, Pelicci PG, Ranga U, Kundu TK. The multifunctional protein nucleophosmin (NPM1) is a human linker histone H1 chaperone. Biochemistry. 2011;50:2780-9.

12. George EM, Brown DT. Prothymosin alpha is a component of a linker histone chaperone. FEBS Lett. 2010;584:2833-6.

13. Kato K, Okuwaki M, Nagata K. Role of template activating factor-I as a chaperone in linker histone dynamics. J Cell Sci. 2011;124:3254-65.

14. Szerlong HJ, Herman JA, Krause CM, DeLuca JG, Skoultchi A, Winger QA, Prenni JE, Hansen JC. Proteomic characterization of the nucleolar linker histone $\mathrm{H} 1$ interaction network. J Mol Biol. 2015;427:2056-71.

15. Kalashnikova AA, Winkler DD, McBryant SJ, Henderson RK, Herman JA, DeLuca JG, Luger K, Prenni JE, Hansen JC. Linker histone H1.0 interacts with an extensive network of proteins found in the nucleolus. Nucleic Acids Res. 2013;41:4026-35.

16. Kalashnikova AA, Rogge RA, Hansen JC. Linker histone $\mathrm{H} 1$ and protein-protein interactions. Biochim Biophys Acta. 2016;1859:455-61.

17. Ni JQ, Liu LP, Hess D, Rietdorf J, Sun FL. Drosophila ribosomal proteins are associated with linker histone $\mathrm{H} 1$ and suppress gene transcription. Genes Dev. 2006;20:1959-73.

18. Das C, Tyler JK, Churchill ME. The histone shuffle: histone chaperones in an energetic dance. Trends Biochem Sci. 2010;35:476-89.

19. Okuwaki M, Matsumoto K, Tsujimoto M, Nagata K. Function of nucleophosmin/B23, a nucleolar acidic protein, as a histone chaperone. FEBS Lett. 2001;506:272-6.

20. Swaminathan V, Kishore AH, Febitha KK, Kundu TK. Human histone chaperone nucleophosmin enhances acetylation-dependent chromatin transcription. Mol Cell Biol. 2005;25:7534-45.

21. Angelov D, Bondarenko VA, Almagro S, Menoni H, Mongelard F, Hans F, Mietton F, Studitsky VM, Hamiche A, Dimitrov S, Bouvet P. Nucleolin is a histone chaperone with FACT-like activity and assists remodeling of nucleosomes. EMBO J. 2006;25:1669-79.

22. Holmberg Olausson K, Elsir T, Moazemi Goudarzi K, Nister M, Lindstrom MS. NPM1 histone chaperone is upregulated in glioblastoma to promote cell survival and maintain nucleolar shape. Sci Rep. 2015;5:16495.

23. Belotserkovskaya R, Oh S, Bondarenko VA, Orphanides G, Studitsky VM, Reinberg D. FACT facilitates transcription-dependent nucleosome alteration. Science. 2003;301:1090-3.

24. Li J, Zhou F, Zhan D, Gao Q, Cui N, Li J, lakhiaeva E, Zwieb C, Lin B, Wong J. A novel histone $\mathrm{H} 4$ arginine 3 methylation-sensitive histone $\mathrm{H} 4$ binding activity and transcriptional regulatory function for signal recognition particle subunits SRP68 and SRP72. J Biol Chem. 2012;287:40641-51.

25. Eliseeva IA, Kim ER, Guryanov SG, Ovchinnikov LP, Lyabin DN. Y-box-binding protein 1 (YB-1) and its functions. Biochemistry (Mosc). 2011;76:1402-33.

26. Kim K, Choi J, Heo K, Kim H, Levens D, Kohno K, Johnson EM, Brock HW, An W. Isolation and characterization of a novel H1.2 complex that acts as a repressor of p53-mediated transcription. J Biol Chem. 2008; 283:9113-26.
27. Horiuchi K, Kawamura T, Iwanari H, Ohashi R, Naito M, Kodama T, Hamakubo T. Identification of Wilms' tumor 1-associating protein complex and its role in alternative splicing and the cell cycle. J Biol Chem. 2013;288:33292-302.

28. Schwartz S, Mumbach MR, Jovanovic M, Wang T, Maciag K, Bushkin GG, Mertins P, Ter-Ovanesyan D, Habib N, Cacchiarelli D, Sanjana NE, Freinkman E, Pacold ME, Satija R, Mikkelsen TS, Hacohen N, Zhang F, Carr SA, Lander ES, Regev A. Perturbation of m6A writers reveals two distinct classes of mRNA methylation at internal and 5' sites. Cell Rep. 2014;8:284-96.

29. Ping XL, Sun BF, Wang L, Xiao W, Yang X, Wang WJ, Adhikari S, Shi Y, Lv Y, Chen YS, Zhao X, Li A, Yang Y, Dahal U, Lou XM, Liu X, Huang J, Yuan WP, Zhu XF, Cheng T, Zhao YL, Wang X, Rendtlew Danielsen JM, Liu F, Yang YG. Mammalian WTAP is a regulatory subunit of the RNA N6-methyladenosine methyltransferase. Cell Res. 2014;24:177-89.

30. Liu J, Yue Y, Han D, Wang X, Fu Y, Zhang L, Jia G, Yu M, Lu Z, Deng X, Dai Q, Chen W, He C. A METTL3-METTL14 complex mediates mammalian nuclear RNA N6-adenosine methylation. Nat Chem Biol. 2014;10:93-5.

31. Xiao W, Adhikari S, Dahal U, Chen YS, Hao YJ, Sun BF, Sun HY, Li A, Ping XL, Lai WY, Wang $X$, Ma HL, Huang CM, Yang Y, Huang N, Jiang GB, Wang HL, Zhou Q, Wang XJ, Zhao YL, Yang YG. Nuclear m(6)A Reader YTHDC1 Regulates mRNA Splicing. Mol Cell. 2016;61:507-19.

32. Xu C, Liu K, Ahmed H, Loppnau P, Schapira M, Min J. Structural basis for the discriminative recognition of N6-methyladenosine RNA by the human YT521-B homology domain family of proteins. J Biol Chem. 2015;290:24902-13.

33. Xu C, Wang X, Liu K, Roundtree IA, Tempel W, Li Y, Lu Z, He C, Min J. Structural basis for selective binding of m6A RNA by the YTHDC1 YTH domain. Nat Chem Biol. 2014;10:927-9.

34. Zhang Z, Theler D, Kaminska KH, Hiller M, de la Grange P, Pudimat R, Rafalska I, Heinrich B, Bujnicki JM, Allain FH, Stamm S. The YTH domain is a novel RNA binding domain. J Biol Chem. 2010;285:14701-10.

35. Zhang S, Cai M, Zhang S, Xu S, Chen S, Chen X, Chen C, Gu J. Interaction of p58(PITSLRE), a G2/M-specific protein kinase, with cyclin D3. J Biol Chem. 2002;277:35314-22.

36. Mueller $\mathrm{CL}$, Jaehning JA. Ctr9, Rtf1, and Leo1 are components of the Paf1/RNA polymerase II complex. Mol Cell Biol. 2002;22:1971-80.

37. Kim K, Lee B, Kim J, Choi J, Kim JM, Xiong Y, Roeder RG, An W. Linker Histone H1.2 cooperates with Cul4A and PAF1 to drive H4K31 ubiquitylation-mediated transactivation. Cell Rep. 2013;5:1690-703.

38. Nishiyama M, Skoultchi Al, Nakayama Kl. Histone $\mathrm{H} 1$ recruitment by CHD8 is essential for suppression of the Wnt-beta-catenin signaling pathway. Mol Cell Biol. 2012;32:501-12

39. Nishiyama M, Oshikawa K, Tsukada Y, Nakagawa T, lemura S, Natsume T, Fan Y, Kikuchi A, Skoultchi Al, Nakayama Kl. CHD8 suppresses p53-mediated apoptosis through histone $\mathrm{H} 1$ recruitment during early embryogenesis. Nat Cell Biol. 2009;11:172-82

40. Krull S, Thyberg J, Bjorkroth B, Rackwitz HR, Cordes VC. Nucleoporins as components of the nuclear pore complex core structure and Tpr as the architectural element of the nuclear basket. Mol Biol Cell. 2004;15:4261-77.

41. Krull S, Dorries J, Boysen B, Reidenbach S, Magnius L, Norder H, Thyberg J, Cordes VC. Protein Tpr is required for establishing nuclear pore-associated zones of heterochromatin exclusion. EMBO J. 2010;29:1659-73.

42. Dieppois $G$, Iglesias N, Stutz F. Cotranscriptional recruitment to the mRNA export receptor Mex67p contributes to nuclear pore anchoring of activated genes. Mol Cell Biol. 2006;26:7858-70.

43. Galy V, Gadal O, Fromont-Racine M, Romano A, Jacquier A, Nehrbass U. Nuclear retention of unspliced mRNAs in yeast is mediated by perinuclear Mlp1. Cell. 2004;116:63-73.

44. Frosst P, Guan T, Subauste C, Hahn K, Gerace L. Tpr is localized within the nuclear basket of the pore complex and has a role in nuclear protein export. J Cell Biol. 2002;156:617-30.

45. Funasaka T, Tsuka E, Wong RW. Regulation of autophagy by nucleoporin Tpr. Sci Rep. 2012;2:878.

46. Herz HM, Garruss A, Shilatifard A. SET for life: biochemical activities and biological functions of SET domain-containing proteins. Trends Biochem Sci. 2013;38:621-39.

47. Smith RW, Blee TK, Gray NK. Poly(A)-binding proteins are required for diverse biological processes in metazoans. Biochem Soc Trans. 2014;42:1229-37.

48. Brook M, Gray NK. The role of mammalian poly(A)-binding proteins in co-ordinating mRNA turnover. Biochem Soc Trans. 2012;40:856-64.

49. Lee JM, Lee JS, Kim H, Kim K, Park H, Kim JY, Lee SH, Kim IS, Kim J, Lee M, Chung CH, Seo SB, Yoon JB, Ko E, Noh DY, Kim KI, Kim KK, Baek SH. EZH2 
generates a methyl degron that is recognized by the DCAF1/DDB1/CUL4 E3 ubiquitin ligase complex. Mol Cell. 2012;48:572-86.

50. Long L, Thelen JP, Furgason M, Haj-Yahya M, Brik A, Cheng D, Peng J, Yao T. The U4/U6 recycling factor SART3 has histone chaperone activity and associates with USP15 to regulate H2B deubiquitination. J Biol Chem. 2014;289:8916-30.

51. Nielsen J, Christiansen J, Lykke-Andersen J, Johnsen AH, Wewer UM, Nielsen FC. A family of insulin-like growth factor II mRNA-binding proteins represses translation in late development. Mol Cell Biol. 1999;19:1262-70.

52. Meergans T, Albig W, Doenecke D. Varied expression patterns of human $\mathrm{H} 1$ histone genes in different cell lines. DNA Cell Biol. 1997;16:1041-9.

53. Parseghian $\mathrm{H}$. What is the role of histone $\mathrm{H} 1$ heterogeneity? A functional model emerges from a 50 year mystery. AIMS Biophysics. 2015;2:724-72.

54. McBryant SJ, Lu X, Hansen JC. Multifunctionality of the linker histones: an emerging role for protein-protein interactions. Cell Res. 2010;20:519-28.

55. Richardson RT, Batova IN, Widgren EE, Zheng LX, Whitfield M, Marzluff WF, O'Rand MG. Characterization of the histone H1-binding protein, NASP, as a cell cycle-regulated somatic protein. J Biol Chem. 2000;275:30378-86.

56. Wang H, Walsh ST, Parthun MR. Expanded binding specificity of the human histone chaperone NASP. Nucleic Acids Res. 2008;36:5763-72.

57. Wang H, Ge Z, Walsh ST, Parthun MR. The human histone chaperone sNASP interacts with linker and core histones through distinct mechanisms. Nucleic Acids Res. 2012;40(2):660-9. Epub 2011 Sep 29.

58. Alabert C, Bukowski-Wills JC, Lee SB, Kustatscher G, Nakamura K, de Lima Alves F, Menard P, Mejlvang J, Rappsilber J, Groth A. Nascent chromatin capture proteomics determines chromatin dynamics during DNA replication and identifies unknown fork components. Nat Cell Biol. 2014;16:281-93.

59. Suzuki K, Bose P, Leong-Quong RY, Fujita DJ, Riabowol K. REAP: A two minute cell fractionation method. BMC Res Notes. 2010;3:294.

60. Knapp AR, Ren C, Su X, Lucas DM, Byrd JC, Freitas MA, Parthun MR. Quantitative profiling of histone post-translational modifications by stable isotope labeling. Methods. 2007:41:312-9.

61. Moore, D., and Dowhan, D. Purification and concentration of DNA from aqueous solutions. Curr Protoc Mol Biol. 2002. Chapter 2, Unit 21 A

62. Xu H, Freitas MA. A mass accuracy sensitive probability based scoring algorithm for database searching of tandem mass spectrometry data. BMC Bioinformatics. 2007:8:133.

63. Xu H, Yang L, Freitas MA. A robust linear regression based algorithm for automated evaluation of peptide identifications from shotgun proteomics by use of reversed-phase liquid chromatography retention time. BMC Bioinformatics. 2008;9:347.

64. Xu H, Zhang L, Freitas MA. Identification and characterization of disulfide bonds in proteins and peptides from tandem MS data by use of the MassMatrix MS/MS search engine. J Proteome Res. 2008;7:138-44.

65. Xu H, Freitas MA. Monte carlo simulation-based algorithms for analysis of shotgun proteomic data. J Proteome Res. 2008;7:2605-15.

66. Zhang B, Chambers MC, Tabb DL. Proteomic parsimony through bipartite graph analysis improves accuracy and transparency. J Proteome Res. 2007;6:3549-57.

67. McCloy RA, Rogers S, Caldon CE, Lorca T, Castro A, Burgess A. Partial inhibition of $C \mathrm{dk} 1$ in $\mathrm{G} 2$ phase overrides the $\mathrm{SAC}$ and decouples mitotic events. Cell Cycle. 2014;13:1400-12.

68. Ge Z, Wang H, Parthun MR. Nuclear Hat1p complex (NuB4) components participate in DNA repair-linked chromatin reassembly. J Biol Chem. 2011;286:16790-9.

\section{Submit your next manuscript to BioMed Central and we will help you at every step:}

- We accept pre-submission inquiries

- Our selector tool helps you to find the most relevant journal

- We provide round the clock customer support

- Convenient online submission

- Thorough peer review

- Inclusion in PubMed and all major indexing services

- Maximum visibility for your research

Submit your manuscript at www.biomedcentral.com/submit 